\title{
SATISFACTION OF OPEN EDUCATION STUDENTS ABOUT THE LEARNING MATERIALS OF MATHEMATICS
}

\author{
Dr. Nevin MAHIR \\ ORCID: 0000-0003-3728-1953 \\ Open Education Faculty, Anadolu University \\ Eskisehir, TURKEY \\ Dr. Fikret Er \\ ORCID: 0000-0002-0194-616X \\ Open Education Faculty, Anadolu University \\ Eskisehir, TURKEY
}

Dr. Bunyamin DEMIR

ORCID: 0000-0002-2560-8392

Faculty of Science, Eskisehir Technical University

Eskisehir, TURKEY

Dr. Namik Kemal ERDOGAN

ORCID: 0000-0002-3630-1660

Faculty of Business Administration, Anadolu University

Eskisehir, TURKEY

Dr. Harun SONMEZ

ORCID: 0000-0003-1082-4073

Open Education Faculty, Anadolu University

Eskisehir, TURKEY

Rusen YILMAZ

ORCID: 0000-0001-6602-5073

Open Education Faculty, Anadolu University

Eskisehir, TURKEY

Received: 12/08/2020 Accepted: 27/08/2020

\begin{abstract}
Changes and developments that take place in technology also cause changes in education and learning. In defining the sufficiency, appropriacy and sustainability of new student services, knowing about the student satisfaction levels carry an imporant role. For this purpose, this study aimed to find about the student satisfaction level regarding the education services provided for Mathematics I class in the Open Education system at Anadolu University, Turkiye. In this study, student satisfaction levels regarding the learning materials such as printed Mathematics I course book, e-book, e-seminars, e-exam, e-learning, face-to-face learning, all of which are presented to the students for Mathematics I class are examined. In order to determine the student satisfaction level regarding the education services provided for Mathematics I class in the Open Education system; a questionnaire was given to the Mathematics class students who take the class in six different cities. Based on the data gathered, the highest satisfaction level of the students is face-to-face learning whereas the lowest one is the television programmes.
\end{abstract}

Keywords: Student satisfaction, Mathematics I, learning materials, open education. 


\section{INTRODUCTION}

The changes and developments that take place in technology also cause changes in education and learning. In the distance education where the Internet and similar techonologies are used, in parallel to the developing techonology, new learning environments and new learning materials are being designed and applied (Naveh et al., 2010). Along with the developing information and communication technologies in distance learning, new programmes are being opened and therefore, the number of new students and student profiles are constantly changing.

As a sign for the education and general quality of an educational organisation, student satisfaction can be shown (Goho and Blackman, 2009). Marozzi (2012) stated that defining the student satisfaction is a key concept for higher educational organisations. Teachers play an important role in determining the general quality of the syllabus and curriculum, and also the student satisfaction (Martin-Rodriguez et al., 2015). Marozzi (2012) pointed out that, with regards to the changes done in the educational organisations, there could be changes in the student satisfaction levels, and thus the student satisfaction should be constantly evaluated.

Anadolu University is a university which designs and applies new learning environments and new learning materials by following and using the recent technological developments in distance education. In addition to the student services that are developed and changed in time, increase in student numbers, changes in student profiles and opening of new programmes affect the student satisfaction in general. It is important to know the student satisfaction levels in determining the sufficiency and appropriacy of the developed and changed student services. From this perspective, the study aimed to determine the student satisfaction levels regarding the student services provided for Mathematics I class which is available in most of the programmes in Open Education system at Anadolu University. For this reason, the materials that are presented for Mathematics I class have been examined are as follows: Printed Mathematics I course book, e-book, e-seminar, e-exam, e-learning, face-to-face learning, television programmes.

\section{LITERATURE REVIEW}

In the literatue, Oliver (1999) described the word 'satisfaction' as the perception that a service has been accomplished in a pleasing way. According to the dictionary, it is "the good feeling that you have when you have achieved something or when something that you want to happen does happen" (Oxford Advanced Learner's Dictionary, 1989).

Zakariya et al. (2020) has studied Self-efficacy and approaches to learning mathematics among engineering students. Their findings show that a high sense of perceived self-efficacy has a strong tendency to induce a deep approach to learning mathematics. In contrast, a low sense of perceived self-efficacy induces a surface approach to learning mathematics with a strong effect. This study represents a shift from the usual correla- tional studies that characterize quantitative research in mathematcs education literature to causal relation research. Therein, causal assumptions are made and tested against the collected data, and some recommendations are made for future studies.

Kantoglu et al. (2013) stated that the satisfaction of a customer is a key component in the success of company and the long-term competition goals. Within this context, they pointed out that the planning that is carried out during this time is based on carrying out the customer demands on the time and place given, and also to ensure their satisfaction in general.

Sahin (2009), by stating that the universities were interested in total quality management and customer satisfaction in a way that is increasing day by day, included Flood's definition as the human centred managing system which aims to increase total quality management and customer satisfaction in a permanent way (Flood, 1993). Customer satisfaction is defined as the fact that the customer is pleased with a product or service that meets a customer's needs or expectations (Zainol et al., 2012). In the presentation of education and learning services, traditional marketing logic is generally adopted (Jurkowitsch et al., 2006: Enache and Brodsky, 2011). In a type of education where marketing strategies are used, student satisfaction is reported to be a part of these strategies. 
Sahney et al. (2004) showed the students to be in the first-place customers among the other customers in the higher education. If the students are seen as the customers of higher education, then they should be customers that are satisfied, which leads more students to come (Thomas and Galambos, 2004). Oliver and DeSarbo (1989) defined student satisfaction as "students' evaluating various outcomes about the education and their experiences in a personal way." Based on the studies carried out, it is possible to see the importance that the universities give to defining the student satisfaction levels.

Zakariya (2019) studies approaches in higher education mathematics: investigating the statistical behaviour of an instrument translated into Norwegian. The revised two-factor study process questionnaire (R-SPQ-2F) has widely been considered valid and reliable in many contexts for measuring students' learning approaches. However, its cultural specificity has generated considerable discussion, with inconclusive results when translated to different languages. The findings of this study provide empirical evidence for the cultural specificity of the instrument that is consistent with the literature. The R-SPQ-2F is therefore recommended to assess students' approaches to learning, and further studies into its cultural specificity are recommended.

Goho and Blackman (2009) stated that student satisfaction can be an indicator of general quality of the organisation and the education it provides. According to Thomas and Galambos (2004), student satisfaction is a reflection of "an aim that provides a rewarding and pleasing environment." Student satisfaction play an important role in evaluating the general quality of teachers, curriculum and syllabus (Martin-Rodriguez et al., 2015). Sahin (2009), in his study, stated that universities aim to be in the higher places among other universities by taking student satisfaction to the higher levels and lowering the dissatisfaction as much as possible. Many colleges and universities use the data gathered from student satisfaction in order to evaluate their organisational efficiency (Beltyukova and Fox, 2002). In their studies, Elliot and Shin (2002) pointed out that higher education organisations give much importance to satisfaction in the mission statements, objectives and introduction activities. A number of studies show the necessity of defining student satisfaction for an educational organisation to continue its existence and also to increase its quality.

Student satisfaction is being constantly shaped by the experiences revoling around the campus life (Elliott and Shin, 2002). Student satisfaction is generally accepted as a short-term manner, resulting from evaluating the education experience of the student (Elliott and Healy, 2001).

In their study, Erdogan and Usak (2007), pointed out that since student motivation is connected with student satisfaction and their academic success, it is basic to meet student expectations and their needs. Marozzi (2012) stated that in order to define the strengths of the higher education orgsanisations and the areas to be improved, student satisfaction should be evaluated in a meticuluous way. As a reason, he showed the increasing number of students in the higher education, increase in the educational services and the new models that are being developed.

Student satisfaction has a multi-dimensional and complicated nature in an organisation has educational and learning activities (Benjamin, 1994; Elliot and Shin 2002). Eygu and Karaman (2013) stated that this fact can be examined with an approach that includes different dimension like educational quality, physical environment, application opportunities presented, socio-cultural and spotie activities, individual qualities of the student. In their studies, they examined the satisfaction perceptions of the students regarding the distance education they were having. They showed that the scale they developed was suitable to determine the satisfaction level of the students under 8 categories (individual appropriacy, efficiency, learning, programme evaluation, technology, material evalution).

In their study, Erdogan and Usak (2007), with regards to evaluating Science teacher-candidates' satisfaction levels, took into consideration various features such as general satisfaction, management, curriculum, academic staff, facilities, courses and skills developed in the laboratories.

Information and communication technologies have affected contemporary societies and economies as well as the education in a common manner (Martin et al., 2015).

The developments in the Internet and information techonologies have also caused a variety of changes in the methods of education and learning in the distance learning. These changes enriched the learning environments with developing technology suich as text, audio, video and animation. In this way, richened environments are also called "multi-media environments" at the same time. Thus, appropriate learning environments can be provided for students with different learning styles. 
The Internet has provided a new mechanism that connects students and teachers. In a study Heinich et al. (2002) carried out, they found out that multi-media environments can increase the motivation. Wu (2014) researched about the connected between satisfaction and learning styles in the distance education. In his study, he took into consideration visual, audiotry, read/write and kinaesthetic learning styles (VARK).

E-learning is a distance learning method in which learning services are provided on a web platform to teachers, students and other useless regardless of location and time (Arbaugh, 2002; Sun, 2008). In e-learning, student satisfaction is an important issue as the new technology affects the student interaction with their peers and teachers (Kaminski et al. 2009).

In e-learning, student satisfaction can be evulated among with other factors such as success, performance, technology and interaction. With regards to satisfaction in e-learning, Bower (2001) emphasised that access to the content, the interaction between student and teachers, time control and cost should be taken into consideration. Palmet and Holt (2010) drew attention to technological factors, whereas Hye-Junk et al. (2009) drew the attention towards interaction factors in the satisfaction of e-learning. Sun and others (2008) proposed a model which included social and technical factors. Apart from these, Kantoglu et al. (2013) also proposed a model which aimed to examine the factors that affect the student satisfaction. In their models, they examined the student satisfaction under five dimensions. Their model included student attention and attitude, the quality of course material and accountability of individual progress, problems accessing to and convenience of the system, efficiency and actuality of the materials, and finally, the quality of the support services. In another study, the connection between the variables of the student satisfaction and the model has been researched with regards to the teaching quality, student interaction, individual appropriacy, factual learning, active learning student anatonmy (Sahin, 2007).

In relation to Mathematics, in this postgraduate thesis, Davis (2014) tried to define the student satisfaction and perfomance via a questionnaire he himself developed. Shukla et al. (2014) looks a comparison of delivery methods for distance learning mathematics courses. The implementation of this study has enabled them to collect data and evidence about the effectiveness of varied distance learning delivery method for curriculum development purposes through the use of grades, teacher observations and a comparison of students' performance in core mathematics courses and mathematical related major courses. A comparison is made of the techniques, experiences, applications and data that are being utilized in the different formats. Topics discussed will include logistics, online resources, and form of assessments, curriculum development, and indications of a review of the results.

As it can be seen from the literature, it can be seen that in defining the appropriacy and sufficiency of the developed and changed teaching servies, it is essential to know the level of student satisfaction. Marozzi (2012) pointed out that, because of the changes carried out in educational organisations, there could be changes in student satisfaction and thus the student satisfaction should be regularly checked.

\section{METHOD}

In this study, a questionnaire form has been designed in order to learn the student satisfaction regarding the services provided in Mathematics I class at Anadolu University Open Education system. In this questionnaire, there are 20 questions which ask about the satisfaction regarding printed Mathematics I course book, e-book, e-seminar, e-exam, e-learning, face-to-face learning and television programmes along with other 7 questions about students' demographic information. Satisfaction questionnaire has been designed within the context of 5-point Likert scale. An official permit regarding the use of the questionnaire is obtained from Anadolu University Ethics Board. The population of the study is the Economy and Management students who studied at Anadolu University Open Education system in 2016-2017 Academic year. 207 students from Istanbul, Ankara, Izmir, Antalya, Trabzon and Eskisehir participated in the questionnarie. These are the students who actively participate in face-to-face classes provided to open education students. The reliability of the students' answers to questionnarie is measured by Cronbach's $\bigotimes$. All the statistical analysis of the data is carried out by SPSS 24 . 


\section{Data Analysis}

The data analysis is carried out by SPSS 24 . The initial cleaning process of the data is carried out then a descriptive analysis of the data is created. Then the students' answers to the questionnaire are analysed to see their satisfaction levels about the services they receive. In order to choose a sample of students, stratified sampling is used. Stratified sampling is a common type of sampling in such applications. This method is done by dividing the main group into one or more sub-groups and creating a new sampling from each sub-group as a result. Each sub-group is called a stratum. Whereas units that create these strata have the common features as the other strata based on the variables, they must show great differences when compared to the others in the other strata. Furthermore, all the units in the main group will be present in only one stratum, and it must be structured so that no main group unit will be left out. In this case, as each stratum will be considered as a main group, the most appropriate sampling can be applied to these strata. In the end, Stratified Sampling can be described as applying the known sampling applications on the present strata. Applying the Simple Random Sampling method to the strata that are created in the main group is called Stratified Random Sampling.

\section{EDUCATION SERVICES PROVIDED IN OPEN EDUCATION SYSTEM FOR MATHEMATICS Printed Mathematics I Course Book}

Printed Mathematics I course book is the primary learning tool that the Open Education system provides for the student. Using the developing technology, this book is designed so that the students can learn on their own and in a way that it would be different than the previous Mathematics course book. Striking differences are that it makes use of dialogue telling, benefits a lot from real life examples, mentions the histrorical development of the topics and uses side explanations to emphasise some of the points elaborated. These issues are described in detail.

\section{Dialogue Telling in Teaching}

As opposed to the traditional way, the printed Mathematics I course book tells the topics using dialogues. This method is an ancient way that can be even found in Platon's books (BC $5^{\text {th }}$ and $4^{\text {th }}$ centuries). The topics are discussed by two teachers and four students. The questions that may come to the mind of the students are asked by the students in the dialogues, discussed by them and in the end, the answers are again found by them. When distance learning is taken into consideration, one of the most important problems for the students is the lack of concentration. Under normal teaching and learning environments, the students can be naturally made ready to learn the topics through the help of the teachers present. The advantage of dialogue telling is that it increases students' motivation and it can lure the students into a classroom atmosphere whether they are at their homes, workplaces or a public transportation. The choice of two teachers help the lesson move away from its monotony. Moreover, in the dialogues, there has been an effort to move the Mathematics topic into its course as naturally as possible. In this way, the focus of the students will be more easily drawn to the target topic. When the topic is being discussed, the key points are asked by the students and the answers are provided by the teachers; at other points, the students are asked to brainstorm their way into the correct answer. Thanks to this approach, a warm and friendly classroom atmosphere is planned to be created. To illustrate, beginning the polymonial, a teacher and three students are having a dialogue in Figure 1 (Kocak and Erdogan, 2017). 
98 lira fatura geldi, ne kadar konușmuș olabilirim ki! Ayrıca taksici de 25 lira aldi.

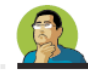

Ne kadar konuştuğunu sen daha iyi bilirsin tabii. Ama bunu bu konuyla ilgili konuşacaktık. İstersen önce taksi hesabını yapalım.

Figure 1. Dialogue about Polynomials

The dialog given in Figure 1 is as follows:

- Selcuk, you are out of breath, what have you been up to?

- Dear Mete, My mood is changed since I saw the phone bill this morning. Additionally I had to take a cab to catch my class. Looks like it will be a tough month.

- Not again Selcuk! The amount of Money you pay for your phone bill is not the problem but it is a pity that you spent too much time on your phone. Also It looks like you can't handle your expenses.

- My phone bill is 98 Turkish liras, how long could I have spoken on the phone?

- You are the one to know how much time you spent on the phone. But it is not too difficult to calculate, Selcuk. We were going to talk about on this issue today. Let's study your taxi bill first.

\section{Real Life Examples}

The topics in the printed Mathematics I course book have been explained through examples selected from real life. Including real life examples in the introduction and presentation of topics will be answer to the question "what good will this topic do to me?" and it will also draw the attention of the students. This method motivates students in the distance learning system more than the method adopted in the traditional teaching. Of course, this situation is not applicable for every topic in Mathematics. However, even the most abstract topic in the course book has been tried to be associated with a real-life event. Examples from the notes in music and marginal value in Economy can be seen. The reading texts at the end of each unit will also help the students. In Figure 2, an example about the real-life situation regarding Polynomial can be seen (Kocak and Erdogan, 2017).

\footnotetext{
(a)

Telefon faturan da basit bir mantıkla hesaplanıyor Selçuk, taksimetrenin çalışma prensibine benziyor. Diyelim ki 20 lira sabit ücret ödüyorsun ve konuşma limitini geçince de bir dakika için fazladan 30 kuruş ödüyorsun. Bu durumda fazladan konuştuğun dakika sayısına $x$ dersen, fazladan ödemen gereken tutar $0,3 x$ lira ve dolaylsıyla ödemen gereken toplam tutar $0,3 x+20$ lira olacaktır.

Aslında ben 15 lira sabit ücret ödüyorum ve üç saat konușmadan sonra, yani limiti geçince de her dakika için 20 kuruş ödüyorum hocam, öğrenci tarifesi.
}

Figure 2. A real-life example for Polynomials 
The dialog given in Figure 2 is as follows:

- Your phone bill, Selcuk, is calculated by a simple logic that is also used for calculating taxi-meters. Suppose you pay 20 Turkish Liras for a fixed period and when you get over the limit/period you pay extra 0.30 Turkish Liras for every minute. If you let $x$ as the minutes you spent extra, the extra money you should pay is $0.30 x$ and therefore the total amount you owe to the phone company is $0.30 x+20$ Turkish Liras.

- Actually, I am paying 15 Turkish liras as fixed period charge and after three hours talking time, that is the limit, I pay extra 0.20 Turkish Liras per minute, that is the student tariff.

\section{Historical Accounts about Mathematics}

In the introduction of some topics, Mathematics history has been used. In this way, the fact that scientists have contributed to the topics through some efforts in time has been emphasised. This situation was affected sometimes by a problem surging or sometimes by an intellectual curiosity. Therefore, Mathematics is not a branch of science a certain person or people created in a specific time in history. Mentioning these processes during the introduction of topics will draw the students' attention. Knowing that Mathematics is product of the humans and not some other world's science will help student want to learn more. Thanks to these reasons, even in secondary school course books, Mathematicsal history is included. In addition to this, in Mathematics I course book, how Harezmi solved the quadratic equated as can be seen in Figure 3 (Kocak and Erdogan, 2017).

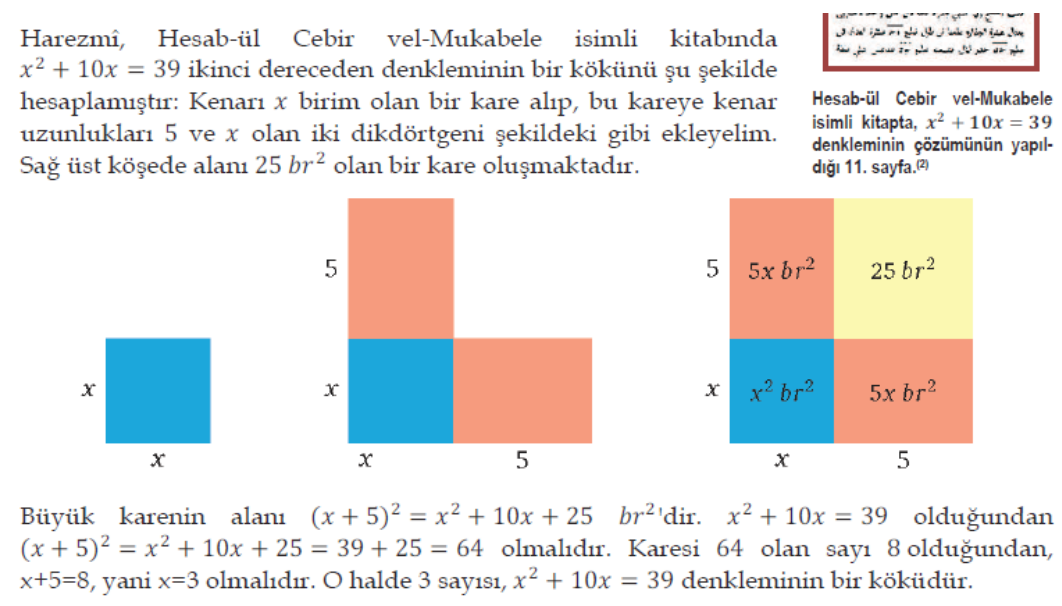

Figure 3. An example for Mathematics history

\section{Side Notes}

In the printed Mathematics I course book, pictures, graphics and introductions which will make understanding easier are given in side notes. Definitions and formulas along with other information that the students will have easy access to have been given in the sides of the main paragraph. To illustrate, as can be seen in Figure 4 where irrational numbers are explained, Pythagorean Theorem has been explained through a side activity (Kocak and Erdogan, 2017). 


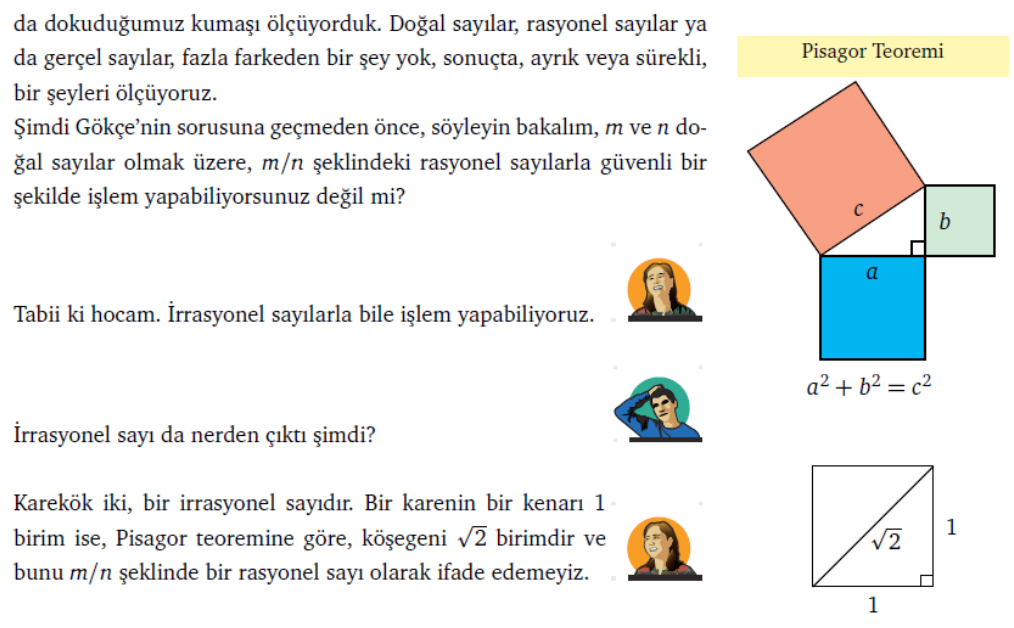

Figure 4. Pythagorean Theorem

With such features, the book is more than a course book, and it turns into a book that raises curiosity about the topics it includes. Also, the summaries and "papers out" parts at the end of each unit enables students to reinforce what they have learnt so far. At the same time, when a student who cannot study except a time that is close to the exam dates is taken into consideration, reading the dialogues will be seen as a waste of time and the student will just study the questions that can be asked in the exam. A student in this situation will prefer a straightforward telling and a book which possibly includes a section called "questions that may be asked in the exam and their answers." By using the Internet effectively, Open Education system aims to meet the needs of the students through practice exams, summary parts and questions from the previous exams.

\section{e-Book}

Interactive e-book presents something more than a book. A fully interactive learning environment, e-book, which is enriched by multimedia elements such as audio, video and animation has been designed to draw the learner to the centre of learning and so that efficient learning can take place more easily. Desktop computers, laptops, tablets or cell phones...Windows, Mac, iOS or Android... They make no difference! Interactive e-books are always read at every place. One of the most important principles of Interactive e-book Project is that it is independent from a platform. Students can use all of the interactive e-books without needing any kind of equipment of software, but using their desktops, laptops or smarthpones. (http://aop.eogrenme.anadolu. edu.tr/ sayfalar/etkilesimli-ekitap.aspx). Figure 5 shows the use of such platform, explaning the cluster topic.

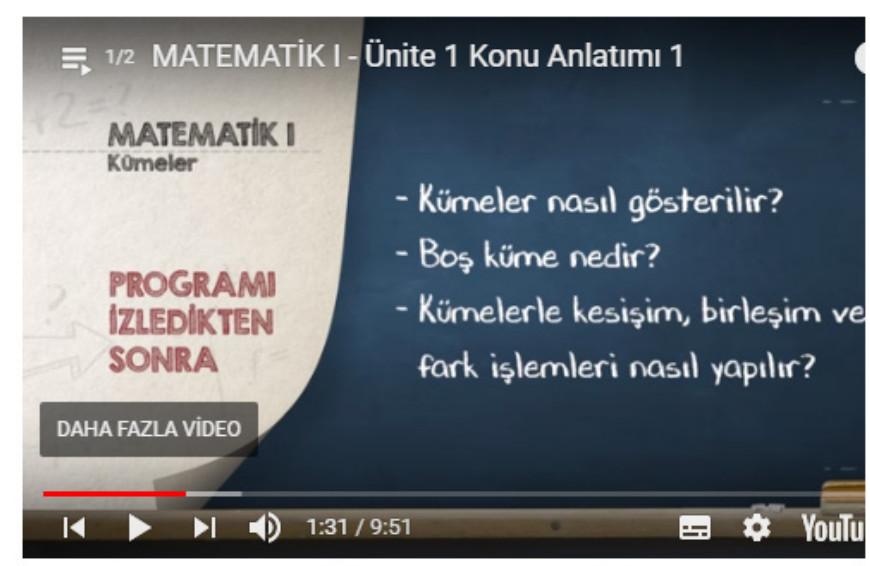

Figure 5. Interactive Teaching of Mathematics course book 


\section{e-Seminar}

Designed as a virtual classroom application, e-Seminar Project enables open education students to participate in the online face-to-face lesson on the Internet. Students can actively take part in the seminar and ask questions. Lasting for a full academic year, e-seminars take place every week with a full unit of the course.

\section{e-Exam}

Prepared exams consist of 20 questions. Students have the opportunity to test themselves and complete what they are missing in the courses. For each exam, a new set of questions get prepared for the students.

\section{e-Learning}

e-Learning can be called as the learning in an electronic environment. In other words, it is the web-based education, learning and information managed, all of which are carried out through Internet technologies. While it has some positive aspects, there are also some negative aspects, as well.

Positive aspects of e-learning

- Students decide when to learn

- Wherever there is Internet, the sources are within reach

- Information can be reached again and again

- It saves money on cost of education

Negative aspects of e-learning

- Students need to have enough knowledge about e-learning

- There are difficulties in transferring the traditional course content

- There might be problems about the feedback

- The reliability of the published information

In order to develop e-learning, the equipment and software tools need to be developed as well. Equipment includes personal computers, media applications and ever-accessible Internet servers. Software tools are developed by the people who does the e-learning presentations according to the need. Developed by Anadolu University Open Education Faculty, the portal named Anadolum is one of such creation. Anadolum is a systematic design with a modular structure which presents the open and distance learning service as a package in a general way. Just as new modules can be added to this design, old modules can also be excluded from it. The fact that the designs the organisations that give distance learning services as an institution under normal circumstances do not have an integral layout has been the reason behind Anadolum Project. The fact that modules can work independently and that, at the same time, they can also work in connection with the other modules is the main purpose of the whole project. (https://farukerdogan.wordpress.com/2009/02/23/e-ogrenmenin-faydalari).

By focusing on the learning and communication technologies, Anadolum e-Campus System is a project that aims to move interaction to higher levels and to increase student motivation. e-Campus System includes: Learning Management Sysmte (OYS), Following the Learner Analytics, Live Lessons (e-seminar) Platform, e-book, e-exam and mobile application (https://ekampus.anadolu.edu.tr/).

\section{Face-to-face Learning}

Anadolu University Open Education System provides face-to-face learning which enables students to ask about the topics they couldn't understand it in the Mathematics I classes done by the teachers. This service is provided in the evenings during weekdays or at the weekends. People who take this service are students who have trouble learning on their own. Open Education faculty take help from teachers from other universities in order to keep this service going. The teachers who are responsible for the lessons tell the topic based on the content and later answer the questions asked by students.

\section{Television Programmes}

According to the agreement done with TRT-School, programmes that are prepared in the TV production centres for the purpose of open education lessons are broadcast. Before the exam, live solutions of the questions are done and students participate in the programme with their questions. In the following days, these 
programmes that are recorded live can be watched on the Internet. Apart from this, television programmes which are prepared with pieces from Mathematics history, contemporary and real life in accordance with Mathematics I course book content are also broadcast. Figure 6 shows an excerpt from a programme in which students participate with their questions.

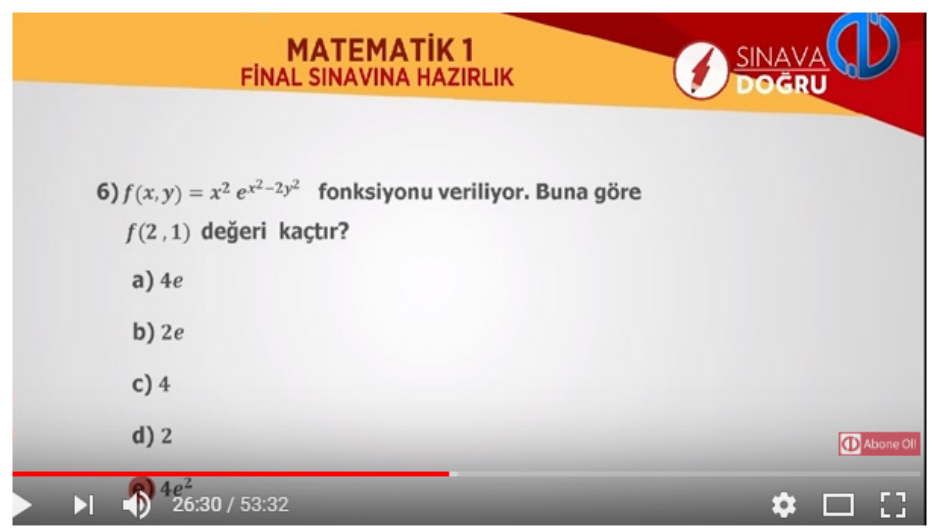

Figure 6. An Example of a question directed by a student

\section{FINDINGS}

In this part, the findings and the comments of the data gathered from the students who are taking Mathematics I lesson at Anadolu University Open Education System is given in detail. This data, which has been taken in a questionnaire designed to define student satisfaction, will have been statistically evaluated before it is interpreted in a meaningful way.

\section{Gemographical Characteristics of the Participants}

In Table 1, 7 questions about the demographic information of 207 students who took Mathematics I class and the data gathered from these questions can be seen.

Table 1. Demographic information of the participants

\begin{tabular}{llll}
\hline Questions & Options & $\mathrm{N}$ \\
\hline \multirow{2}{*}{ Which programme are you registered on Open Education system? } & Management & 127 & 61.4 \\
& Economy & 80 & 38.6 \\
\hline & 18 and under & 19 & 9.2 \\
Your age? & $19-24$ & 93 & 44.9 \\
& $25-34$ & 56 & 27.1 \\
& $35-44$ & 23 & 11.1 \\
\hline \multirow{2}{*}{ 3- Gender? } & 45 and above & 16 & 7.7 \\
\hline \multirow{2}{*}{ 4-Have you ever studied in a higher education organisation before? } & Yes & 122 & 58.9 \\
& No & 88 & 41.1 \\
\hline \multirow{2}{*}{ 5- Do you work? } & Yes & 60 & 29 \\
& Male & 147 & 71 \\
\hline \multirow{2}{*}{ 6- Can you use a computer as much as necessary? } & No & 88 & 42.5 \\
& Yes & 119 & 57.5 \\
\hline
\end{tabular}


As can be seen in Table 2, 61.4\% of the participants are students at Faculty of Economy whereas the rest $38.6 \%$ are students at Faculty of Management.

According to the data given in Table 2, 45\% of the participants area aged between 19 and 24 . However, the rate of participants at the age of 25 or above is around $49.5 \%$. As a policy of life-long learning, Anadolu University Open Education system gives students a great opportunity to get their diplomas. When the percentages are taken into consideration, the number of students at their normal age for university is almost the same as the number of students in higher ages.

According to the data in the Table, the number of female students in this study is around 58.9\%.

Question 4 was asked to define whether there were any students who already finished a degree in another higher education programme and who entered Anadolu University Open Education system. Within the light of this, $29 \%$ of the students were reported to have gotten education from another higher education programme, which supports the idea that the number of individuals who want to get a diploma thanks to the life-long learning philosophy has started to increase. $71 \%$ of the students have never studied at a higher education programme before.

Question 5 was prepared to define the number of students who were also working. According to the data, nearly $43 \%$ of the students are working.

Question 6 was prepared to define the students' attitude toward using computers. According to the data, 85\% of the students who participated in the study stated that they were using computer as much as it was necessary. The fact that the study showed a high percentage of computer usage is a sign that students can be given extra computer materials especially in a lesson like Mathematics. Extra materials like live lessons, problem solving, sample event explanations and e-seminar will affect students' learning experiences in a positive way. For this reason, Anadolu University provides such services from a website, ekampus.anadolu.edu.tr.

Taking a look at the frequency of how much Internet the students used, it can be said that a majority of the students were using the Internet every day or 3-4 days every week. The sum of these two categories were found out to be around $91.8 \%$. As a result, it is clear that the student can have easy access to the support services that are given on the Internet.

\section{Findings Related to Student Satisfaction}

There are 20 questions below which asked about the satisfaction levels of the students regarding the printed Mathematics I course book, e-book, e-seminar, e-learning, face-to-face learning and television programmes. Also, in Table 2, to gather the data, a three-way scale has been adopted in order to better see the results.

In the first question in Table 2, whether the fact that the book was written in dialogues was eye-opening and interesting for the student was studied. According to the results, $34.3 \%$ of the students stated that dialogue telling is eye-opening and interesting. In the second question, the promoting effect of dialogue telling was studied. According to the data, $29 \%$ of the students found dialogue telling effective. The third question included students' views regarding the effect of real life samples on the information itself. Accordign to the results, $30.9 \%$ of the students stated that the real-life examples enabled them to focus more on the information.

According to the data gathered from the fourth question, 29\% of the students stated that including the history of Mathematics I in the course book in some of the topics made it easy for them to learn. Including more of the history in the course books to be written in the future, this issue can have a facilitating effect. In the fifth question, 29\% of the students stated that the printed Mathematics I course book increased their motivation to learn. According to the data gathered from the sixth question which asked about whether the other course books should include dialogue telling, $29.5 \%$ of the students leaned towards the idea that other course books can be written in in the same style. For the seventh question, the percentage of the students who thought that the pictures, graphics and explanations in the course book made it easier for them to learn was found to be $41 \%$. 
Table 2. Survey questions and answers organised in to 3 level Likert scale

\begin{tabular}{|c|c|c|c|}
\hline \multirow[t]{2}{*}{ Questions } & \multirow{2}{*}{ Disagree } & \multirow{2}{*}{$\begin{array}{l}\text { Undecided } \\
\%\end{array}$} & \multirow{2}{*}{ Agree } \\
\hline & & & \\
\hline $\begin{array}{l}\text { The fact that Mathematics I course book was written in dialogues was eye-opening } \\
\text { and interesting. }\end{array}$ & 49.3 & 16.4 & 34.3 \\
\hline $\begin{array}{l}\text { The fact that Mathematics I course book was written in dialogues promoted me to } \\
\text { study. }\end{array}$ & 51.2 & 19.8 & 29.0 \\
\hline $\begin{array}{l}\text { The fact that the topics in the Mathematics I course book was told through real life } \\
\text { events enabled me to focus on the information. }\end{array}$ & 46.9 & 22.2 & 30.9 \\
\hline $\begin{array}{l}\text { The fact that some of the topics in the Mathematics I course book was told from the } \\
\text { history of Mathematics made it easy for me to learn. }\end{array}$ & 45.4 & 25.6 & 29.0 \\
\hline Printed Mathematics I course book increased my motivation to learn. & 51.7 & 19.3 & 29.0 \\
\hline I wish other course books were written in dialogues. & 55.1 & 15.5 & 29.5 \\
\hline $\begin{array}{l}\text { The pictures, graphics and explanations in the Mathematics I course book made it } \\
\text { easy for me to understand. }\end{array}$ & 32.4 & 26.6 & 41.1 \\
\hline I prefer Mathematics I e-book to study than the printed material. & 22.8 & 46.1 & 31.1 \\
\hline $\begin{array}{l}\text { In the interactive e-Mathematics I book, multimedia acitivies such as audio, video } \\
\text { and animation made me interested in the lesson. }\end{array}$ & 23.7 & 30.4 & 45.9 \\
\hline $\begin{array}{l}\text { Because the e-Mathematics I book provided multi media learning environment with } \\
\text { audio, video and animation, my learning performance increased. }\end{array}$ & 26.1 & 29.5 & 44.4 \\
\hline $\begin{array}{l}\text { Because the e-Mathematics I book provided multi media learning environment with } \\
\text { audio, video and animation, I studied in my own style. }\end{array}$ & 23.8 & 25.2 & 51.0 \\
\hline $\begin{array}{l}\text { In the concurrent e-seminar activity, I learnt more easily by asking the parts I had } \\
\text { trouble understanding. }\end{array}$ & 22.2 & 34.8 & 43.0 \\
\hline $\begin{array}{l}\text { When I couldn't participate in the e-seminar acitivity, I watched the videos on the } \\
\text { e-learning platform and I found it efficient. }\end{array}$ & 24.8 & 29.6 & 45.6 \\
\hline $\begin{array}{l}\text { In the e-seminar activity, I think that I got enough information from the instructors } \\
\text { who were doing the activity. }\end{array}$ & 24.2 & 34.3 & 41.5 \\
\hline $\begin{array}{l}\text { Practice exams of the Mathematics I lesson helped me to find and define the } \\
\text { problems and issues in my learning. }\end{array}$ & 20.8 & 29.0 & 50.2 \\
\hline I think that the practices exams of the Mathematics I lesson will increase my success. & 19.8 & 22.7 & 57.5 \\
\hline E-learning about Mathematics I enabled me to study on my own pace. & 17.9 & 37.2 & 44.9 \\
\hline I prefer the e-learning of Mathematics I to the traditional learning. & 31.9 & 36.7 & 31.4 \\
\hline $\begin{array}{l}\text { I learnt the topics of the Mathematics I lesson easier in the academic support lessons } \\
\text { that are done face-to-face. }\end{array}$ & 15.0 & 14.0 & 71.0 \\
\hline $\begin{array}{l}\text { Because the television programmes of the Mathematics I lesson included current } \\
\text { and real-life examples, they were interesting and informing. }\end{array}$ & 34.8 & 36.7 & 28.5 \\
\hline
\end{tabular}

According to the eighth question which showed students' preferences of using e-book rather than printed Mathematics I book, the percentage of students who preferred e-book is 31.1, whereas the undecided percentage stayed at 46.1 . For the ninth question, $45.9 \%$ of the students were attracted to the supplementary material such as video, audio and animation in Mathematics I course book. According to the data gathered from the tenth question, $44.4 \%$ of the students regarded the supplementary materials like audio, video and animations as increasing their performance. According to the eleventh question, the percentage of the students who stated that they liked working in their own style was $51 \%$. 
According to the question twelve, $43 \%$ of the students said that they learnt the topics they had trouble understanding easily thanks to the e-seminar activity. In question thirteen, the number of students who continued their learning experiences even if they couldn't participate in the concurrent e-seminar activities was around $45.6 \%$. This situation can be as an indicator that these e-seminar activities should go on in the future. For question fourteen, $41.5 \%$ of the students thought that they take enough feedback from the instructors who were doing the e-seminar activities in the Mathematics I lesson. As a result, increasing the interaction between students and instructors can also increase students' learning experiences.

Question fifteen was asked to define students' views about the practice exams. According to the data gathered, $50.2 \%$ of the students stated that the practice tests were helpful in defining their mistakes and problems they were having in the Mathematics I lesson. This situation can be an indicator that such practices can continue in the future. According to the data gathered from question sixteen, $57.5 \%$ of the students thought that practice exams increase their success in the exams.

Question seventeen aimed to find the relationship between e-learning and students' pace. According to the data, $44.9 \%$ of the students thought that e-learning in Mathematics I lesson enabled them to study at their oown pace. Question eighteen looked at the student preferences between e-learning and traditional learning. According to the data, $31.4 \%$ of the students prefer e-learning to traditional learning.

The percentage of the students who stated that they learnt better in the face-to-face academic support Mathematics I lessons was found to be $71 \%$. Based on the data, it can be said that continuing the face-toface education services can contribute more to the student's general learning and their success in the exams.

Question twenty reflects the view regarding the television programmes. Accordign to the data, $28.5 \%$ of the students thought that the television programmes were eye-opening and interesting as they included contemporary and real-life examples. More materials from this area can be developed in the years to come.

\section{CONCLUSION}

This research which was carried out with students who took Mathematics I lesson within the context of Anadolu University Open Education system was done with the permit of Anadolu University Scientific Research Commision's 01.07.2016 and 11/5 file number. The project was within the context of a title accepted by the Commission under the project number 1606E533 and the statement "Student satisfaction regarding the Mathematics I lesson given in the Open Education sytem." In this part of the study, the findings about the printed Mathematics I course book, e-book, e-seminar, e-exam, e-learning, face-to-face learning and television programmes about the Mathematics I lesson will be given in detail. In the study, according to the demographic information of the students, the difference between the the levels of satisfaction regarding the Mathematics I lesson in the Open Education system was found to be low. While this finding is parallel to what Davis (2014) proved in thesis that student satisfaction did not change according to the gender, the study contradicts his findings with regards to the age. In his thesis that studied the student satisfaction according to the age, he stated that "younger students were more satisfied with online Mathematicss courses than older students."

The seven questions were designed to ask about the student satisfaction about the printed course book, dialogue telling, explaining the topics through real life examples, making use of Mathematics history and side explanations. In the seventh question where the student satisfaction is high, students stated that the pictures, graphics and the animations in the Mathematics I course book made it easy for students to understand the topic. As a result, it can be said that such use of pictures, graphics and animations along with other supportive visual details affect student satisfaction in a positive way. To illustrate, Eisenberg and Dreyfus argue that when one uses functions, one should "see" a diagram, and this visual interpretation should be just as dominant in the mind as the analytic formulation. 
In the examining of student satisfaction regarding the e-Mathematics I book (8-11), as the e-book provided multi media materials such as audio, video and animation, the rate of students who stated that they worked best for their own style is higher than the others. The student satisfaction regarding the e-book was found out to be higher than the satisfaction with the printed course-book. As Sahin and Yildirim (1999) stated, the fact that the learning materials have the ability to carry the content from abstract to something concerete and that they make the learning easier by using audio-visual features has affected the student satisfaction in a positive manner.

As for the student satisfaction regarding e-seminar, the rate of students who stated that they could ask the areas they had trouble understanding and the rate of students who stated that they could take sufficient feedback from the instructors are close to one another. Since these rates are twice the percentage as the students who have negative opinions, it shows that the student satisfaction should be increased nonetheless. Sahin (2007) stated that "although distance education is a learner-centered instruction, this finding confirms that instructor support, such as timely help, useful feedback, or easy communication, is still a key factor for student satisfaction in distance learning. Thus, instructors of distance education should be accessible, provide prompt responses, and encourage their students through online learning activities." With these words, he emphasised the support that the instructors could give to the distance education.

According to the data gathered from the e-exam satisfaction, the rate of the students who thought that the practice exams increase their success in the general exams is really high. The students, who cannot spare enough time to study, who think reading the dialogues is a waste of time and who studies the questions that may be asked in the exams, can be the reason for this finding.

Based on the data gathered from the satisfaction findings about the e-learning, the number of students who stated that they would prefer e-learning to traditional learning was found out to be even. This situation is supported by Kendall's (2001) statement that "online courses can achieve the student success and learning outcomes, though not so much as traditiona courses."

According to the data about the face-to-face learning of the Mathematics I lesson, the percentage of the students who stated that they learnt the topics easier in the academic support lessons is higher than the other satisfaction questions asked in the questionnaire. This situation supports the statement by Rodriguez and others: "Even though students may have opted for e-learning freely, they still express a high regard for contact with their professor and classmates."

As for the student satisfaction regarding the television programmes, the number of students who thought that the television programmes are interesting and informing as they included contemporary and real-life examples was found out to be the lowest among other questions that asked about the satisfaction levels.

Universities are expected to meet the needs and expectations of the students, and therefore, it is essential to find about what the students give importance to and what they are less satisfied with (Elliott and Shin, 2002). Within this light, in this study, whereas the rate of students who are satisfied with face-to-face learning is highest, the satisfaction level for the television programmes is the lowest. Yildirim et al. (2015) stated that the lower satisfaction areas in the universities are indicators of where some improvements should be made in order to increase the student satisfaction in those areas. According to this, it can be said that further action should be taken into consideration regarding the television programmes of Mathematics I lesson so as to increase the student satisfaction in this area.

The fact that this study included students only from six cities that gave Mathematics I lesson is a limitation in itself. Therefore, in the researches to be carried out in the future, it can be suggested that all students that take Mathematics I lesson in the Open Education system can be included in the questionnaire. Apart from these, the reasons why certain student satisfaction levels were found to be so low can also be researched in the future studies. 


\section{BIODATA and CONTACT ADDRESSES of AUTHORS}

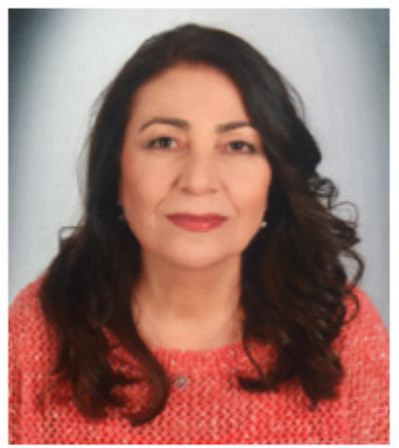

Dr. Nevin MAHIR is working as an Associate Professor at Open Education Faculty, Anadolu University. She received her B.S. degree in Mathematics from Ankara University, Turkey and her Ph.D. degree in Applied Mathematics from Eskisehir Osmangazi University, Turkey. She has done some studies on Mathematics Education. She contributed to a mathematics book in Open and Distance Education Faculty. Her research interest is open and distance mathematics education.

Nevin MAHIR

Distance Education Department, Faculty of Open Education

Address: Anadolu University, 26470, Eskisehir, Turkey

Phone: +90-222-3350580

Email: nemahir@anadolu.edu.tr

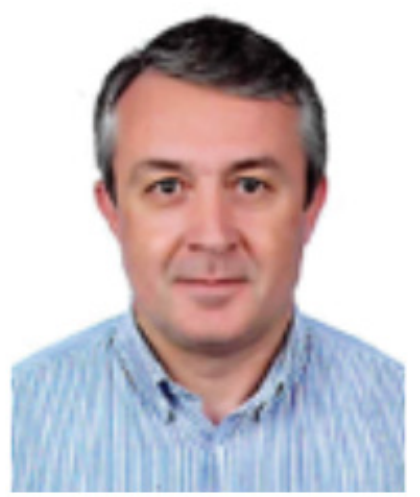

Dr. Fikret ER is working as a Professor at Open Education Faculty, Anadolu University. He received his B.S. degree in Statistics from Anadolu University, Turkey and her Ph.D. degree in Statistics from University of Leeds, England. He studies statistical shape analysis, data mining and decision making. He has been teaching statistics, data mining and advanced research methods courses in undergraduate and graduate level in different faculties. He is working on applications of AI and ML in open education system.

Fikret ER

Open Education Faculty Address: Anadolu University, Open Education Faculty, Yunus Emre Campus, 26470, Eskisehir, Turkey Phone: +90-222-3350580

Email: fer@anadolu.edu.tr

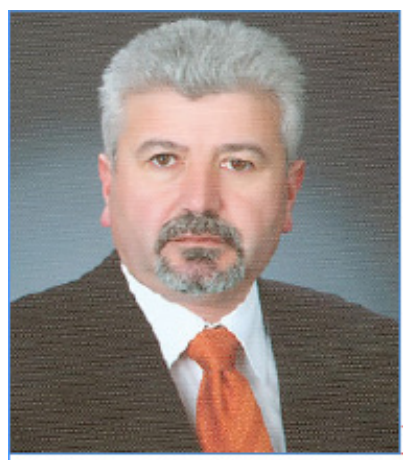

Dr. Bunyamin DEMIR is working at Science Faculty, Eskisehir Technical University. He received his Ph.D. degree in Applied Mathematics from Eskisehir Osmangazi University, Turkey. He contributed to a mathematics book in Open and Distance Education Faculty. His research interests are fractals and chaotic dynamical systems. He is also interested in history of mathematics.

Bunyamin DEMIR

Mathematics Department, Faculty of Science

Address: Eskisehir Technical University, 26470, Eskisehir, Turkey

Phone: +90-222-3350580

Email: bdemir@eskisehir.edu.tr 


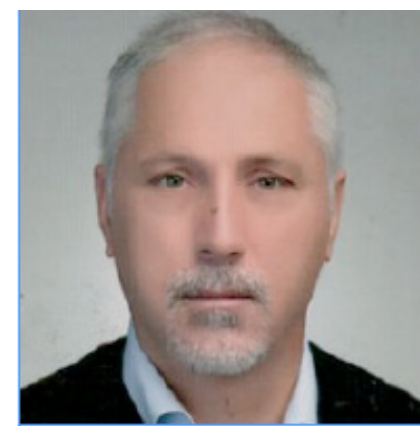

Dr. Namik Kemal ERDOGAN is working as an Associate Professor at Faculty of Business Administration, Anadolu University. He received B.S. degree in Mathematics from Anadolu University, Turkey and his Ph.D. degree in Applied Mathematics from Eskisehir Osmangazi University, Turkey. He has done some studies on Operation Research. He contributed to a mathematics book of Open Education Faculty.

Namik Kemal ERDOGAN

Faculty of Business Administration

Address: Anadolu University, 26470, Eskisehir, Turkey

Phone: +90-222-3350580

Email: nkerdoga@anadolu.edu.tr

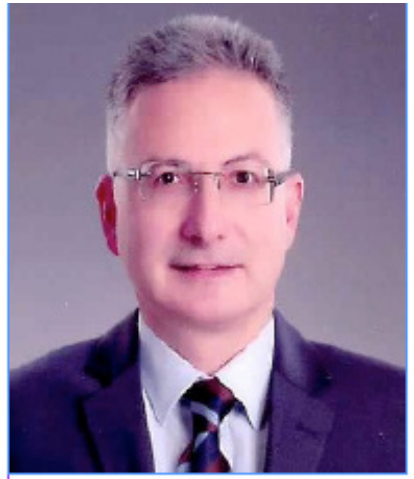

Dr. Harun SONMEZ is a Professor of Open and Distance Education at Open Education Faculty, Anadolu University. Dr. Sonmez gained his Ph.D. in Statistics at March, 2001. His academic interest areas are applied statistics, multivariate statistics, data mining, statistical package programs. He has over than 28 journal articles published in international indexes, 14 international and national books and book chapters other national and international articles, papers submitted to international meetings.

\section{Harun SONMEZ}

Department of Distance Education, Open Education Faculty Address: Anadolu University, 26470, Eskisehir, Turkey

Phone: +90 2223350580,

E-mail: hsonmez@anadolu.edu.tr

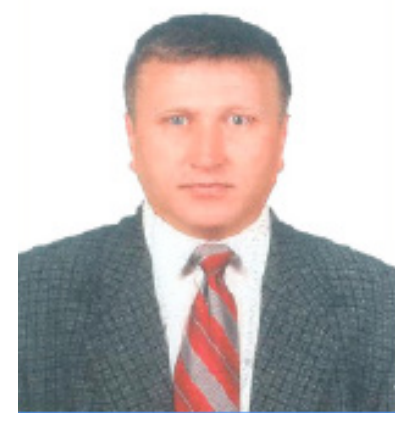

Rusen YILMAZ is an Instructor of Open and Distance Education at Open Education Faculty, Anadolu University. His academic interest areas are educational hypermedia and multimedia, educational interfaces, open and distance learning, education futures, e-learning and use of internet in education. He has 5 papers submitted to international meetings.

\section{Rusen YILMAZ}

Department of Distance Education, Open Education Faculty

Address: Anadolu University, 26170, Eskisehir, Turkiye

Phone: +90 5424852979,

E-mail: ryilmaz@anadolu.edu.tr 


\section{REFERENCES}

Anadolum e-Campus Portal, https://ekampus.anadolu.edu.tr/

Anadolu University Open Education e-Learning Portal, aop.eogrenme.anadolu.edu.tr/sayfalar/ etkilesimliekitap.aspx

Arbaugh, J.B. (2002). Managing hte online classroom: Astudy of tecnological and behavioral characteristics of web based MBA courses. The Journal of High Technology Management Research, 13, 203-223.

Beltyukova, S. A., \& Fox, C. M. (2002). Student satisfaction as a measure of student development: Towards a university metrics. Journal of College Student Development, 43,161-169.

Benjamin, M. (1994). The quality of student life: Toward a coherent conceptualization. Social Indicators Research, 31. 205-264. doi:10.1007/BF01078209

Bower, B. (2001). Distance education: Facing the faculty challenge. Online Journal of Distance Learning Administration, 4(2).

Davis, A. M. (2014). Measuring Student Satisfaction in Online Math Courses, Theses and Dissertations, Universty of Kentucky UKnowledge.

Eisenberg, T., and T. Dreyfus. 1994. On Understanding how students learn to visualize function transformations. CBMS, Issues in Mathematics Education. 4:45-68.

Elliott, K. M., \& Healy, M.A. (2001), Key Factors Influencing Student Satisfaction Related to Recruitment and Retention, Journal of Marketing for Higher Education, Vol. 10(4)

Elliott, K. M., \& Shin, D. (2002). Student satisfaction: An alternative approach to assessing this important concept. Journal of Higher Education Policy and Management, 24, 197-209.

Enache, I. C., \& Brodsky, Z. (2011). Student behavior and student satisfaction: A marketing approach. Scientific Papers of the University of Pardubice. Series D, Faculty of Economics \& Administration, $16,43-52$.

Erdogan, F., (2009), https://farukerdogan.wordpress.com/2009/02/23/e-ogrenmenin-faydalari

Erdogan, M., Usak, M. (2007). Examining prospective science teacher's satisfaction with their department. Science Education International, Vol. 18, No. 4, 277-288

Eygu, H., Karaman, S. (2013) Uzaktan Egitim Ogrencilerinin Memnuniyet Algilari Uzerine Bir Arastirma, Kirikkale Universitesi Sosyal Bilimler Dergisi Cilt 3 Sayi 1

Flood, R.L. (1993). Beyond TQM. New York, NY: John Wiley \& Sons.

Goho, J., \& Blackman, A. (2009, Winter/Spring). Improving the reporting of student satisfaction surveys through factor analysis. AIR Professional File, 111, 1-16.

Heinich, R., Molenda, M., Russell, JD., Smaldino, ES., (2002), Instructional Media and Technologies for Learning. Merrill Prenticehall.

Hornby, A.S., Chief Editor: Cowie, A.P. (1989). Oxford Advanced Learner's Dictionary, Fourt Edition, Great Britain: Oxford University press.

Hye-Junk, L.\& Rha, I. (2009). Influence of Structure and Interaction on Student Achievement and Satisfaction in Web-Based Distance Learning. Journal of Educational Technology \& Society, 12(4), 372-382

Jurkowitsch, S., Vignali, C. and Kaufmann, H. R. (2006). A student satisfaction model for Austrian higher education providers considering aspects of marketing communications, Innovative Marketing, Volume 2, Issue 3, 2006

Kaminski, K., Switzer, j. \& Gloeckner, G. (2009). Workforce readiness: A study of university students' fluency with information technology, Computers \& Education 53(2), 228-233 
Kantoglu, B., Torkul, O., \& Altunisik, R. (2013). E-ogrenmede Ogrenci Memnuniyetini Etkileyen Faktorlerin Incelenmesine Yonelik Model Onerisi, Business and Economics Research Journal, Vol: 4, Num: 1.

Kendall, M. (2001). Teaching online to campus-based students: the experience of using WebCT for the community information module at Manchester Metropolitan University. Education for Information, 19(4) 325-346.

Kocak, S., \& Erdogan, N. K., (Eds.) (2017), Matematik I, Eskisehir, Anadolu Universitesi Yayinlari.

Marozzi, M. (2012). Tertiary student satisfaction with socialization: A statistical assessment, Quality and Quantity, 46, 1271-1278.

Mustafa, Z., Basri, N., Abidin, N. Z, Suradi, N. R. M., Ali, Z. M., Shahabudin, F. A. A., \& Associates (2012). Modeling of student satisfaction. Journal of Mathematics and Statistics, 8, 64-71.

Naveh, G., Tubin, D., \& Pliskin, N. (2010). Student LMS use and satisfaction in academic institutions: The organizational perspective. The Internet and Higher Education, 13(3), 127-133

Oliver, R. L. (1999). Whence consumer loyalty? Journal of Marketing, 63, 33-44.

Oliver, R. L., \& DeSarbo, W. S. (1989). Processing satisfaction response in consumption: A suggested framework and research proposition. Journal of Consumer Satisfaction, Dissatisfaction, and Complaining Behavior, 2, 1-16.

Palmer, S.\& Holt, D. (2010). Students' perceptions of the value of the elements of an online learning environment: looking back in moving forward. Interactive Learning Enviroments, 18(2), 135-151

Rodriguez, O., Molina, J., Alonso, M. and Gomez, F. (2015), The main components of satisfaction with e-learning, Technology, Pedagogy and Education, 2015 Vol. 24, No. 2, 267-277

Sahney, S., Banwet, D.K. ve Karunes, S. (2004). A SERVQUAL and QFD approach to total quality education: A student perspective. International Journal of Productivity and Performance Management, 52(1), $143-166$.

Shukla, N. J.; Hassani H., and Casleton R. (2014) A Comparison of Delivery Methods for Distance Learning Mathematics Courses, SoTL Commons Conference. 75.

Sun, P.C., Tsai, R.J., Figer, G., Chen, Y.Y. \& Yeh, D. (2008). What drives a successful e-learning? An empirical investigation of the critical factors influencing learner satisfaction. Computer \& Education, 50(4), 1183-1202.

Sahin, A. E. (2009). Egitim fakultesinde hizmet kalitesinin egitim fakultesi memnuniyeti olcegi (EF-OMO) ile degerlendirilmesi, Hacettepe Universitesi Egitim Fakultesi Dergisi, 37, 106-122.

Sahin, I. (2007). Predicting Student Satisfaction in Distance Education and Learning Environments, TOJDE, Vol: 8 , Num: 2

Sahin, T. Y. ve Yildirim, S. (1999). Ogretim Teknolojileri ve Materyal Gelistirme. Ankara: Ani Yayincilik.

Thomas, E. H., \& Galambos, N. (2004). What satisfied students? Mining student-opinion data with regression and decision tree analysis. Research in Higher Education, 45, 251-269

Wu, D. C. (2014). Learning Styles and Satisfaction in Distance Education,TOJDE, Vol:15, Num: 4

Yildirim, B.F., Guneri, Y.O. ve Aydin, C.Y. (2015). Universite Ogrencilerinin Memnuniyet Duzeyi ve Iliskili Degiskenler, Egitimde Kuram ve Uygulama, 11(2), 521-533

Zakariya, Y.F. Study (2019). Approaches in Higher Education Mathematics: Investigating the Statistical Behaviour of an Instrument Translated into Norwegian. Education Sciences, 9, 191.

Zakariya, Y.F., Nilsen H. K., Simon Goodchild \& Kirsten Bjørkestøl (2020). Self-efficacy and approaches to learning mathematics among engineering students: empirical evidence for potential causal relations, International Journal of Mathematical Education in Science and Technology 